\title{
COMPARASION OF THE RESULTS OF CORNEAL TOPOGRAPHY FINDINGS IN FUCHS ENDOTHELIAL DYSTROPHY AND PSEUDOPHAKIC BULLOUS KERATOPATHY
}

\author{
Ayyildiz Taha \\ Department of Opthalmology, Ahi Evran University Medicine Faculty, Kırşehir Turkey
}

Primljen/Received 07. 03. 2018. god.

Abstract: Background: Comparison of Fuchs endothelial dystrophy and pseudophakic bullous keratopathy with the help of Scheimpflug camera combined with a Placido disk corneal topographer.

Material and methods: 34 eyes of 34 patients pseudophakic bullous keratopathy (PBK) and 32 eyes of 20 patient Fuchs endothelial dystrophy (FED) have been examined by Scheimpflug camera combined with a Placido disk corneal topographer. Anterior chamber depth (ACD), anterior chamber volume (ACV), iridocorneal angle (ICA), central corneal thickness (CCT) and LogMAR best corrected visual acuity (BCVA) were compared in terms. Except for corneal edema, diseases of the eye that can impair vision (cataracts, glaucoma, retinal disease) were excluded.

Results: The average age of patients in group PBK and FED were found $64.9 \pm 13.9$ and $66.06 \pm 10.5$ respectively. ACD, ACV, ICA, CCT and BCVA in PBK group $2.95 \pm 0.48 \mathrm{~mm}, 202.55 \pm 115.20 \mathrm{~mm}^{3}$, $40.73 \pm 10.44$ derece, $742.41 \pm 108.74 \mu \mathrm{m}$ and $2.06 \pm$ 0.70 LogMAR respectively. ACD, ACV, ICA, CCT and BCVA in FED group $2.63 \pm 0.64 \mathrm{~mm}, 140.75 \pm$ $71.34 \mathrm{~mm}^{3}, 34.62 \pm 13.58$ derece, $757.37 \pm 145.99 \mu \mathrm{m}$ and $1.82 \pm 1.12 \operatorname{LogMAR}$ respectively. Statistically significant difference between the 2 groups in terms of ACV and LogMAR BCVA was observed ( $p=0.01$ and $p=0.001)$. Between other parameters as mean age, $\mathrm{ACD}, \mathrm{ICA}$ and CCT, statistically difference was not observed $(\mathrm{p}>0.05)$.

Conclusions: Between two groups in terms of age, ACD, ICA and CCT statistically significant difference was not significant, while in terms of ACV and BCVA LogMAR observed results showed statistically significant difference $(\mathrm{p}<0.05)$.

Key words: Pseudophakic bullous keratopathy, fuchs endothelial dystrophy, corneal topography, Sirius.
Prihvaćen/Accepted 29. 03. 2018. god.

\section{INTRODUCTION}

Due to endothelial pump function deterioration, fluid accumulation in the extracellular space in the stroma leads to corneal edema (1). As a result of changes in morphological properties of the cornea such as surface irregularities and increased interfibrillary space, there is a decrease in visual acuity, pain, irritation and conjunctival hyperemia.

Pseudophakic bullous keratopathy (PBK) is the leading cause of ocular morbidity in cataract surgeons (2). Fuchs endothelial dystrophy (FED) is the cause of primary endothelial dysfunction characterized by Descemet membrane guttata, endothelial erosion and corneal edema (Figure. 1 and 2). In corneal endothelial dysfunctions, surgical treatment is needed when corneal opacity can not be preserved. PBK and FED accounted for $42.4 \%$ of the 42,000 corneal transplantations in the United States and are the leading causes of corneal transplant surgeons $(3,4,5)$. Figures 1 and 2 show a corneal topographic analysis of the Fuchs endothelial dystrophy in 65-year-old female patient with an anterior segment photograph. Figures 3 and 4 show a corneal

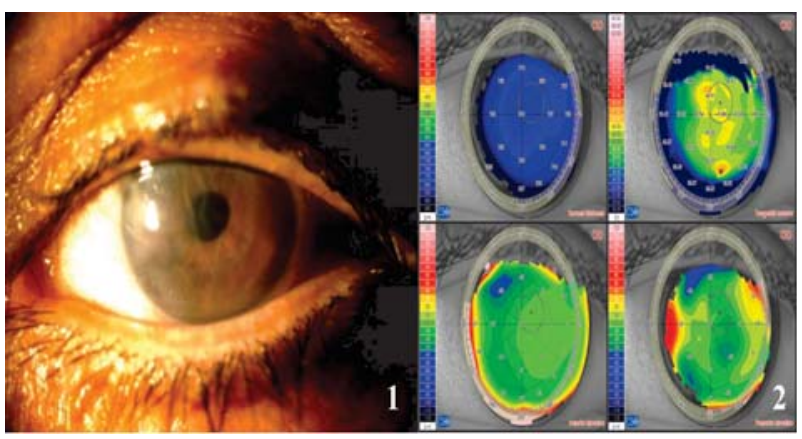

Figure 1. Fuchs Endothelial Dystrophy in female patient aged 65; Figure 2. Sirius corneal topographic analysis of the patient in Figure 1 


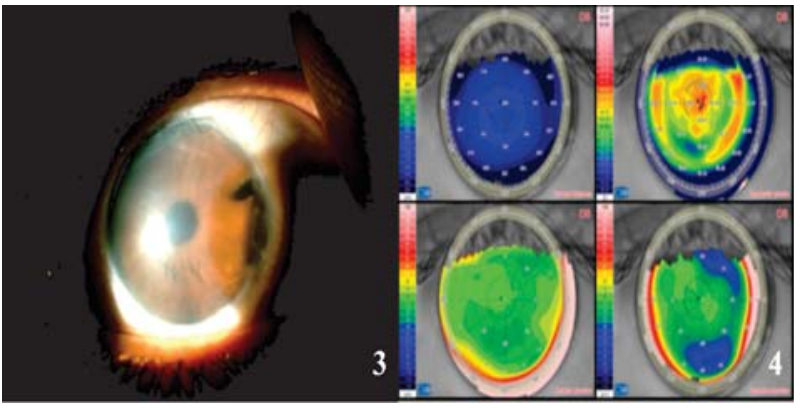

Figure 3. Pseudophakic bullous keratopathy in 50 years old female patient; Figure 4. Sirius corneal topographic analysis of the patient in Figure 3

topographic analysis with an anterior segment photograph of a 50 year old patient with pseudophakic bullous keratopathy.

In this study, we aimed to compare PBK and FED disease, primary and secondary endothelial deficiencies, with the help of Scheimpflug camera combined with a Placido disk corneal topographer.

\section{MATERIAL AND METHOD}

This retrospective study included patients diagnosed with PBK and FED in our ophthalmology department between January 2012 and February 2015. The study was conducted in accordance with the Helsinki declaration rules and by receiving informed consent forms from patients.

34 eyes of 34 patients diagnosed with PBK disease and 32 eyes of 20 patients diagnosed with FED disease were included in this study. Patients included in the study were divided into 2 groups according to their diseases. Detailed ophthalmological examination including visual acuity, intraocular pressure measurement, anterior and posterior segment evaluation, were performed on all subjects. Those with any ocular or systemic disease that could reduce the level of vision other than PBK and FED were excluded from the study.

Corneal topography was then performed to all patients with an anterior segment analysis system of Sirius (Costruzione Strumenti Ophthalmologist, Florence, Italy), which was operated on a combined Scheimpflug-Placido disk system. PBK and FED disease groups were compared in terms of age, LogMAR best corrected visual acuity (BCVA), anterior chamber depth (ACD), anterior chamber volume (ACV), central corneal thickness (CCT), and iridocorneal angle (ICA).

PBK and FED disease groups were compared in terms of age, ACV, ACD, ICA, CCT and BCVA LogMAR and after showing the normal distribution Independent Sample t-test was performed.

SPSS 15.0 (IBM Corporation, Chicago, IL, USA) program was used for statistical analysis. Independent sample t-test and Chi-square test were used in comparison of the data of the two disease groups and $p<0.05$ was considered statistically significant.

\section{Sirius topography}

The device combines a Monchromatic 360 degree rotated Scheimpflug camera and a 22 ring Placido-disk, taking 25 radial sections through the cornea and anterior chamber. It provides with a single cut-sheet tangential and axial curvature information of both surfaces of the cornea, gives the global refractive power of the cornea, provides biometric measurements of most visible structures, and provides pachymetry and wave front analysis of the cornea. Scheimpflug imaging provides all the measurements of other internal structures while the device delivers the corneal anterior surface measurement data in combination with Placido images and Scheimpflug images as appropriate. 35632 points from the corneal anterior surface and 30000 points from the posterior surface of the cornea are examined with $475 \mathrm{~nm}$ blue LED light. Wave front analysis of the cornea with Sirius device is performed by the beam follow-up method $(8,9,10)$.

\section{RESULTS}

Among the eyes analyzed in the PBK group, 19 were female and 15 were male. Among the eyes analyzed in the FED group 16 were males and 16 females. Chi-square test showed no statistically significant difference between the two groups in terms of gender $(p=$ 0.658). The age and measurement parameters of PBK and FED groups are given in Table 1.

Table 1. Independent t test

\begin{tabular}{|l|c|c|c|}
\hline \multicolumn{1}{|c|}{ Parameter } & PBK & FED & $p$ \\
\hline Age & $64 \pm 13.9$ & $66.06 \pm 10.5$ & 0.335 \\
\hline ACD $(\mathrm{mm})$ & $2.95 \pm 0.48$ & $2.63 \pm 0.64$ & 0.651 \\
\hline ACV $\left(\mathrm{mm}^{3}\right)$ & $202.55 \pm 115.20$ & $140.75 \pm 71.34$ & 0.011 \\
\hline ICA $($ degree $)$ & $40.73 \pm 10.44$ & $34.62 \pm 13.58$ & 0.292 \\
\hline CCT $(\mu \mathrm{m})$ & $742.41 \pm 108$ & $757.37 \pm 145$ & 0.343 \\
\hline BCVA logMAR & $2.06 \pm 0.70$ & $1.82 \pm 1.11$ & 0.001 \\
\hline
\end{tabular}

When the PBK and FED groups were compared with the independent sample $t$ test, the frequency of the ACV, PBK group was higher $(p=0.011)$. BCVA was higher in the FED group $(p=0.011)$. There were no significant differences between the two groups in terms of $\operatorname{ACD}(p=0.651), \operatorname{ICA}(p=0.292), \operatorname{CCT}(p=0.343)$ and age $(p=0.335)$. 


\section{DISCUSSION AND CONCLUSION}

In this study we compared pseudophakic bullous keratopathy which is leading cause of secondary endothelial failure and fuchs endothelial dystrophy which is primary endothelial dysfunction cause with the help of combined Scheimpflug-Placido disc system (Costruzione Strumenti Ophthalmics, Florence, Italy) corneal topography device in terms of anterior chamber morphological features whether or not they differ in the course of endothelial failure.

We have observed rear studies comparing FED and PBK patients with corneal topography aid $(6,7)$. In one study, PBK and Fuchs patients were divided into 3 groups according to their corneal thickness via CCT and analysis was performed with Orbscan corneal topography (Bausch\&Lomb Surgical Inc., San Dimas, $\mathrm{CA}$ ). In the same study, none of the variables we evaluated were compared.

As far as we know, this study is one of only few studies in which topographic analysis of cornea is performed in edematous corneas. This study aims to measure the functional and biomechanical properties of human cornea with endothelial decompensation. We also think that the differences between these two groups can be used as a point of view in which endothelial keratoplasty surgery may require different techniques in donor preparation and placement.

Basically, even if endothelial keratoplasty procedure is applied in both diseases, Descemet stripping endothelial keratoplasty (DSEK) surgery uses endothelium and some back stroma while Descemet membrane endothelial keratoplasty (DMEK) surgery uses Descemet membrane together with endothelium only. Donor tissue manipulation and anterior chamber stabilization during graft opening can be a bigger problem for DMEK surgeons. We think that careful surgical technique is needed because of the difficulty of surgery and possible complications, especially in FED patients which have a lower ACV compared to PBK patients. Future studies should support these data.

\section{DECLARATION OF INTEREST}

The autors declare that there are no conflicts of interests.
Abbreviations
PBK - pseudophakic bullous keratopathy
FED - Fuchs endothelial dystrophy
ACD - anterior chamber depth
ACV - anterior chamber volume
ICA - iridocorneal angle
CCT - central corneal thickness
BCVA — best corrected visual acuity

\section{Licensing}

This work is licensed under a Creative Commons Attribution 4.0 International (CC BY 4.0) License

\title{
Sažetak
}

\section{POREĐENJE REZULTATA NALAZA KORNEALNE TOPOGRAFIJE KOD FUCHS-ove ENDOTELIJALNE DISTROFIJE I PSEUDOFAKNE BULOZNE KERATOPATIJE}

\author{
Ayyildiz Taha \\ Department of Opthalmology, Ahi Evran University Medicine Faculty, Kırşehir Turkey
}

Uvod: Poređenje Fuchs-ove endotelijalne distrofije i pseudofakne bulozne keratopatije uz pomoć kombinovanog Scheimplfug kamera-Placido disk topogrfer sistema.

Materijal i metode: 34 oka od 34 pacijenata sa pseudofaknom buloznom keratopatijom (PBK) i 32 oka od 20 pacijenata sa Fuksovom endotelijalnom distrofijom (FED) pregledani su placido-disk kornealnom topografijom kombinovanom sa Scheimpflug kamerom. Dubina prednje očne komore (ACD), volumen prednje očne komore (ACV), iridokornealni ugao (ICA), centralno kornealno zadebljanje (CCT) i najbolja korigovana vidna oštrina (LogMAR BCVA) su bili upoređivani. Osim bolesti povezanih sa korne- alnim edemom, ostale bolesti koje mogu da ugroze vid su bile isključene (katarakta, glaukom, bolesti retine).

Rezultati: Prosečna starost pacijenta u grupama PBK i FED bile su 64,9 $\pm 13,9$ i 66,06 $\pm 10,5$. ACD, ACV, ICA, CCT i BCVA u grupi PBK bile su $2,95 \pm$ $0,48 \mathrm{~mm}, 202,55 \pm 115,20 \mathrm{~mm}^{3}, 40,73 \pm 10,44$ derece, $742,41 \pm 108,74 \mu \mathrm{m}$ and $2,06 \pm 0,70 \mathrm{LogMAR}$. ACD, ACV, ICA, CCT i BCVA u FED grupi bile su 2,63 \pm $0,64 \mathrm{~mm}, 140,75 \pm 71,34 \mathrm{~mm}^{3}, 34,62 \pm 13,58$ derecea, $757,37 \pm 145,99 \mu \mathrm{m}$ and $1,82 \pm 1,12$ LogMAR. Statistička značajnost između 2 grupe u pogledu ACV i logMAR BCVA bile su ispitane $(\mathrm{p}=0,01 \mathrm{i} \mathrm{p}=0,001)$. Ostali parametri srednja starosna vrednost, ACD, ICA i 
CCT izmedju ispitivanih grupa nisu pokazali statističku značajnost $(\mathrm{p}>0,05)$.

Zaključak: Razmeđu dve grupe u pogledu godina, ACD, ICA i CCT nije se pokazala kao statistički

\section{REFERENCES}

1. Feiz V, Mannis MJ, Hollandf EJ. Cornea. 3rd ed. Philadelphia: Mosby Elsevier. 2011; pp.: 283-8.

2. Yi DH, Dana MR. Corneal edema after cataract surgery: incidence and etiology. Semin Ophthalmol. 2002; 17(3-4) 110-4.

3. Cosar CB, Sridhar MS, Cohen EJ, Held EL, Alvim Pde $\mathrm{T}$, Rapuano CJ, et al. Indications for penetrating keratoplasty and associated procedures: 1996-2000. Cornea. 2002; 21(2): $148-51$.

4. Liu E, Slomovic AR. Indications for penetrating keratoplasty in Canada: 1986-1995. Cornea. 1997; 16(4): 414-9.

5. Maeno A, Naor J, Lee HM, Hunter WS, Rootman DS Three decades of corneal transplantation; indications and patient characteristics. Cornea. 2000; 19(1): 7-11.

6. Brunette I, Sherknies D, Terry MA, Chagnon M, Bourges JL, Meunier J.. 3-D characterization of the corneal shape in Fuchs značajna, dok u pogledu ACV i BCVA logMAR rezultati su se statistički značajno razlikovali $(\mathrm{p}<0,05)$.

Ključne reči: pseudofakna bulozna keratopatija; Fuksova endotelijalna distrofija; kornealna topografija; Sirius.

dystrophy and pseudophakic keratopathy. Invest Ophthalmol Vis Sci. 2011; 52(1): 206-14.

7. Laliberte JF, Meunier J, Chagnon M, Kieffer JC, Brunette I. Construction of a 3-D atlas of cornealshape. Invest Ophthalmol Vis Sci. 2007; 48(3): 1072-8.

8. Savini G, Barboni P, Carbonelli M, Hoffer KJ. Repeatability of automatic measurements by a new Scheimpflug camera combined with Placido topography. J Cataract Refract Surg. 2011; 37(10): 1809-16.

9. Savini G, Carbonelli M, Sbreglia A, Barboni P, Deluigi G, Hoffer KJ. Comparison of anterior segment measurements by 3 Scheimpflug tomographers and 1 Placido corneal topographer. J Cataract Refract Surg. 2011; 37(9): 1679-85.

10. Milla M, Pinero DP, Amparo F, Alio JL. Pachymetric measurements with a new Scheimpflug photography-based system: intraobserver repeatability and agreement with optical coherence tomography pachymetry. J Cataract Refract Surg. 2011; 37(2): 310-6.

\section{Correspondence to/Autor za korespondenciju}

Taha AYYILDIZ

Assistant Professor

Ahi Evran University Medicine Faculty

Department of Opthalmology

Kırşehir Türkey

email: obirtahadir@hotmail.com

tel: 00905077559720 